Oleksandr Levchenko, Professor, Doctor in Economics (Doctor of Economic Sciences)

Anna Kryvorotenko, Postgraduate

Central Ukrainian National Technical University, Kropyvnytskyi, Ukraine

\title{
Theoretical Approaches to Determine the Essence of Transfer of Educational Knowledge in the System of Higher Education
}

The purpose of the article is to study the mechanism of knowledge transfer at the current stage of development of the domestic economy, as one of the main principles of cooperation of major players in the economic market. Achieving such a result is possible only with the cooperation of resources and powers of central, regional authorities, local self-government, scientific institutions, educational institutions and enterprises, as well as combining their target guidelines in a single system. The article analyzes the current state of the mechanism of knowledge transfer in the world and in Ukraine.

Knowledge transfer is no easy task and is not something completed overnight, but with careful preparation and clear goals, it can be accomplished and set your organization up for success in the long term. By focusing on the psychological processes that underlie knowledge transfer within a unit and between units within a firm, this special issue complements work in cognitive psychology on knowledge transfer at the individual level of analysis as well as work in strategy and organizational theory on knowledge transfer at the firm or industry levels of analysis. The analysis of the main commercial forms of transfer of realized knowledge. The cycle of transfer of qualitative knowledge between the universities and the manufacturing sector is considered and a classification of the main types of knowledge transfer is given.

The model of the quadruple helix proposed by Itkowitz and its constituent elements is also considered. The relationship between key participants in the knowledge transfer process using the quarter-helix model is investigated. Alternative definitions of the concepts of knowledge transfer and the knowledge transfer center have been proposed. The essence and main advantages of creation of centers of knowledge transfer on a commercial and state basis are revealed. Alternative definitions of the concepts of knowledge transfer and the center of knowledge transfer are proposed. The article analyzes that knowledge transfer is a systematic and purposeful strategy for capturing critical knowledge from key personnel to store and share with within an organization for maximum efficiency. By having a solid, step-by-step strategy to obtain knowledge, the actual transfer of it to relevant parties will be smoother and easier to complete.

knowledge transfer, knowledge, knowledge transfer center, innovation, quarter-helix model, commercial transfer

Одержано (Received) 23.05.2019

Прорецензовано (Reviewed) 30.05.2019

Прийнято до друку (Approved) 04.06.2019

УДК 339.727.3.058.4

JEL Classification: F21

І.М. Миценко, проф., д-р екон. наук

T.B. Решитько, доц., канд. екон. наук

Центральноукраїнський національний технічний університет, м. Кропивницький, Украӥна

\section{Удосконалення системи водопостачання і водовідведення обласного комунального виробничого підприсмства «Дніпро - Кіровоград» за сприяння інвестицій Світового банку}

В статті розглянуто законодавчу та регуляторну базу України у сфері водопостачання, водовідведення та іноземного інвестування. Досліджено характер іноземних інвестицій в рамках проекту «Розвиток міської інфраструктури - 2». Проаналізовано основні напрями інвестиційної діяльності підприємства. Досліджено напрямки інвестиційної діяльності підприємства в рамках співпраці 3 Міжнародним банком реконструкції та розвитку (Світовим банком). Доведено, що реалізація інвестиційного проекту матиме позитивні екологічні та соціальні наслідки

системи водопостачання і водовідведення, якість питної води, іноземні інвестиції, інвестиції Світового банку

(C) I.М. Миценко, Т.В. Решитько, 2019 
И.М. Миценко, проф., д-р экон. наук

T.В. Решитько, доц., канд. экон. наук

Центральноукраинский национальный технический университет, г. Кропивницкий, Украина

Усовершенствование системы водоснабжения и водоотведения областного коммунального производственного предприятия «Днипро - Кировоград» при содействии инвестиций Мирового банка

В статье рассмотрена законодательная и регуляторная база Украины в сфере водоснабжения и водоотведения и иностранного инвестирования. Исследован характер иностранных инвестиций в рамках проекта «Развитие городской инфраструктуры - 2». Проанализированы основные направления инвестиционной деятельности предприятия. Исследованы направления инвестиционной деятельности предприятия в рамках сотрудничества с Международным банком реконструкции и развития (Мировым банком). Доказано, что реализация инвестиционного проекта будет иметь положительные экологические и социальные результаты.

системы водоснабжения и водоотведения, качество питьевой воды, иностранные инвестиции, инвестиции Мирового банка

Постановка проблеми. 3 моменту набуття Україною незалежності на державному рівні розроблено основні засади екологічної політики та ратифіковано важливі міжнародні конвенції. На законодавчому рівні затверджено низку різних національних та державних програм, серед яких: Національна програма екологічного оздоровлення басейну Дніпра, Державна програма поліпшення якості питної води в Україні, Програма розвитку систем водопостачання та водовідведення, Загальнодержавна програма формування національної екологічної мережі України, Загальнодержавна програма охорони та відтворення довкілля Азовського і Чорного морів.

На жаль, згадані вище екологічні програми реалізуються повільно і проблема якості питної води залишається актуальною для нашої країни. Головною проблемою реалізації цих програм є недостатнє фінансування. Необхідний обсяг коштів є більшим, ніж передбачено в природоохоронному фонді Державного бюджету України, а інших механізмів фінансування сьогодні не існує. Пошук шляхів покращення інвестиційної діяльності вітчизняних підприємств та залучення іноземних інвестицій для створення сучасної системи водопостачання і водовідведення населених пунктів Кіровоградської області є надзвичайно важливим. Цим і пояснюється актуальність теми дослідження.

Аналіз останніх досліджень і публікацій. Проблеми формування якісної системи централізованого водопостачання та водовідведення в Україні, знайшли висвітлення в працях багатьох вчених. Відомі вітчизняні науковці М. Гіроль та Г. Семчук вважають, що ефективність систем водопостачання України $\epsilon$ фактором національної безпеки держави [2]. А. Гіроль переконаний, що найбільшою проблемою системи водопостачання України є іiі спрацьованість, яка становить 30 \% [1]. Вчені дослідили, що незадовільний технічний стан системи водопостачання, загалом, та водопровідної мережі, зокрема, негативно позначаються на якості очищеної води і $є$ причиною вторинного ऑiі забруднення. Відновлення ефективної працездатності водопровідної мережі вимагає майже 76 \% коштів, необхідних для відновлення системи в цілому. На думку вчених Д. Ковальського та В. Хомко, реальні можливості забезпечення споживачів чистою водою дає якісна очистка води перед їі подачею в водопровідну мережу, своєчасне відновлення технічного стану водопровідної мережі, володіння необхідними коштами для досягнення належного рівня експлуатації системи тощо [15]. Проте, більшість вчених, у своїх працях зосереджують увагу лише на технічній стороні проблеми, а питання залучення міжнародних інвестицій для вирішення проблеми якості питної води в Україні ще мало вивчено, тому потребує більш детального розгляду та дослідження. 
Постановка завдання. Метою роботи $\epsilon$ дослідження законодавчого регламентування та практичних аспектів щодо формування якісної системи централізованого водопостачання та водовідведення обласного комунального виробничого підприємства «Дніпро - Кіровоград» за сприяння іноземних інвестицій Міжнародного банку реконструкції та розвитку.

Виклад основного матеріалу. Законодавча та регуляторна база України, що регулює екологічні питання, є досить складною. Вона складається 3 міжнародних конвенцій, договорів, протоколів та угод, ратифікованих Верховною Радою України; законів, постанов та розпоряджень Кабінету Міністрів України, наказів міністерств.

Закон України «Про внесення змін до Закону України «Про Загальнодержавну програму «Питна вода України» на 2006-2020 роки» фактично затвердив Національну програму «Питна вода України» на 2011 - 2020 роки. Програмою передбачено, серед іншого, вирішення пріоритетних питань у сфері водопостачання та водовідведення, приведення нормативно-правової бази у сфері питного водопостачання та водовідведення у відповідність із стандартами Європейського Союзу, з урахуванням національних особливостей, у тому числі, підвищення якості питної води та очищення стічних вод [9].

Закон України «Про житлово-комунальні послуги» встановлює принципи державної політики в галузі надання житлово-комунальних послуг, включаючи постачання питної води та відведення стічних вод [8].

Іноземне інвестування посідає особливе місце в структурі зовнішньоекономічних пріоритетів розвитку української економіки. Світовий досвід показує, що акумулюючи підприємницький, державний та змішаний капітал, іноземні інвестиції забезпечують доступ до сучасних технологій та менеджменту, сприяють формуванню національних інвестиційних ринків, активізують ринки товарів і послуг.

Потреба України в іноземних інвестиціях зумовлена низькою інвестиційною активністю власних товаровиробників і підприємств, необхідністю технічної та технологічної модернізації виробництва, всієї ринкової та соціальної інфраструктури.

Серед законодавчих актів щодо іноземного інвестування в Україні слід виділити Закони України «Про режим іноземного інвестування» [13], «Про інвестиційну діяльність» [11], «Про зовнішньоекономічну діяльність» [10], міждержавні угоди «Про сприяння і взаємний захист інвестицій» та інші нормативно-правові акти.

Аналіз вимог законодавства України та політики Світового банку в частині оцінки впливу на навколишнє середовище та плану екологічного управління демонструє значну схожість. Ключовою вимогою, спільною для обох систем, $є$ обов'язкове повномасштабне проведення оцінки впливу на навколишнє середовище для всіх об'єктів «підвищеної екологічної небезпеки» [5].

У 2008 році Україна та Міжнародний банк реконструкції та розвитку (Світовий Банк) підписали Угоду про позику 4869-UA у розмірі 140 млн. доларів США на реалізацію проекту «Розвиток міської інфраструктури» (ПРМІ). ПРМІ включає чотири компоненти: А) Інституційна спроможність; В) Інвестиції на реконструкція; C) Енергоефективність; D) Управління проектом [7].

ПРМІ спрямований на надання допомоги комунальним підприємствам окремо відібраних міст у покращенні якості та надійності послуг, зменшення вартості послуг за допомогою серії інституційних покращень та інвестицій у реконструкцію і заміну зношених систем водопостачання, водовідведення та поводження 3 твердими побутовими відходами.

Уряд України ініціював другу фазу проекту «Розвиток міської інфраструктури» (ПРМІ-2), надіславши Світовому Банку запит на фінансування в розмірі приблизно 250 млн. доларів США. Світовий Банк підтвердив свою зацікавленість у підготовці та 
фінансуванні ПРМІ-2 починаючи 3 другого півріччя 2014 року. Метою ПРМІ-2 є вирішення екологічних та соціальних проблем у вісьмох містах України: Харкові, Кіровограді (нині Кропивницькому), Краматорську, Тернополі, Житомирі, Києві, Коломиї та Донецьку шляхом покращення якості та ефективності послуг 3 водопостачання, водовідведення та поводження з твердими побутовими відходами, що надаються на території відповідних муніципалітетів [12; 16].

Зазначимо, що більшість підприємств водопровідно-каналізаційного господарства (ВКГ) в обраних містах в рамках ПРМІ-2, в т. ч. у м. Кіровограді, на той час були збитковими. Недостатність фінансових надходжень унеможливлювала проведення профілактичних робіт та не дозволяла вчасно покривати експлуатаційні витрати, переважну частину яких становила вартість електроенергії. Більшість електромеханічного обладнання була неефективною та енергозатратною і не відповідала сучасному технологічному рівню. Через недостатнє фінансування, інфраструктура зливу та очищення стічних вод працювала неналежним чином або не працювала взагалі, що спричиняло постійне забруднення водних шляхів.

Обласне комунальне виробниче підприємство (ОКВП) «Дніпро-Кіровоград» $є$ суб’єктом підприємницької діяльності, що здійснює господарську діяльність в сфері водопровідно-каналізаційного господарства з метою задоволення суспільних потреб у продукції, роботах та послугах, поліпшення побутових умов населення Кіровоградської області та соціально-економічних інтересів територіальних громад сіл, селищ і міст області в галузі житлово-комунального господарства. Підприємство надає 80,4 \% обсягу послуг з централізованого водопостачання в області і забезпечує проведення єдиної державної, регіональної науково-технічної та інвестиційної політики, удосконалення організації управління, форм і методів господарювання, розвитку ринкових відносин, підвищення ефективності використання майна спільної власності територіальних громад сіл, селищ і міст Кіровоградської області в галузі житловокомунального господарства.

Засновником ОКВП «Дніпро-Кіровоград» виступає Кіровоградська обласна рада. Департамент житлово-комунального господарства Кіровоградської обласної державної адміністрації забезпечує галузеву політику ОКВП «Дніпро-Кіровоград». Головним напрямом діяльності підприємства $є$ централізоване водопостачання та водовідведення у Кіровоградській області.

ОКВП «Дніпро-Кіровоград» представляє собою цілісний майновий комплекс (гідротехнічні споруди і трубопроводи магістрального районного водопроводу «Дніпро-Кіровоград» та водопровідно-каналізаційні споруди і мережі міст Світловодська, Олександрії, Знам'янки, Кропивницький i селищ міського типу Димитрово та Пантаївка), який обслуговують Світловодське, Олександрійське, Знам'янське та Кіровоградське водопровідно-каналізаційні господарства. На зазначених об' єктах працюють кваліфіковані працівники в кількості 1483 чол. [3 ].

Джерелом водопостачання магістрального районного водопроводу «ДніпроКіровоград» $€$ поверхневі води Кременчуцького водосховища, звідки здійснюється водозабір до Дніпровської водоочисної станції і водопровідних очисних споруд та підземні водозабори «Лелеківський» i «Холодні ключі» до м. Кропивницький i «НовоПилипівський» водозабір - до м. Олександрія. Вони забезпечують питною водою міста обласного підпорядкування, прилеглі сільські населені пункти, де мешкає біля 500 тисяч жителів і зосереджено 70\% всього виробничого потенціалу Кіровоградської області. ОКВП «Дніпро-Кіровоград» надає послуги з централізованого водопостачання у 16 населених пунктах області.

Протягом 2012 р. - 1 півріччя 2018 р. підприємство працювало в умовах збиткових тарифів, постійного приросту вартості енергоносіїв, рівня мінімальної 
заробітної плати, матеріалів, послуг та інших складових тарифу і не мало можливості залучати власні кошти на інвестиційні та капітальні видатки в повному обсязі Інвестиційної програми підприємства.

Про виконання заходів Інвестиційної програми ОКВП «Дніпро-Кіровоград» за рахунок власних коштів у 1 півріччі 2018 року свідчить табл. 1.

Таблиця 1 - Виконання заходів інвестиційної програми ОКВП «ДніпроКіровоград» у 1 півріччі 2018 року

\begin{tabular}{|c|c|c|c|c|c|}
\hline \multirow[b]{2}{*}{$\begin{array}{l}\text { № } \\
3 / \Pi\end{array}$} & \multirow[b]{2}{*}{ Найменування заходів } & \multicolumn{2}{|c|}{ План на 2018 р. } & \multicolumn{2}{|c|}{$\begin{array}{c}\text { Виконано за } 1 \\
\text { півріччя } 2018 \text { p. }\end{array}$} \\
\hline & & $\begin{array}{l}\text { Сума, } \\
\text { тис. грн. } \\
\text { з ПДВ }\end{array}$ & $\begin{array}{l}\text { Сума, } \\
\text { тис. грн. } \\
\text { без ПДВ }\end{array}$ & $\begin{array}{l}\text { Сума, } \\
\text { тис. грн. } \\
\text { з ПДВ }\end{array}$ & $\begin{array}{l}\text { Сума, } \\
\text { тис. } \\
\text { грн. без } \\
\text { ПДВ } \\
\end{array}$ \\
\hline \multicolumn{6}{|c|}{ Водопостачання } \\
\hline 1 & 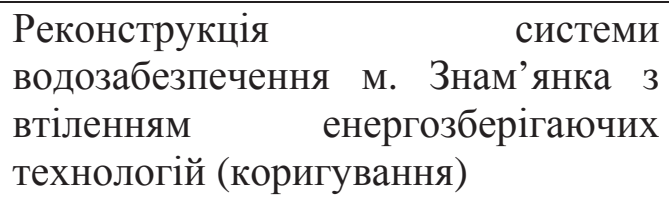 & 343,06 & 285,88 & 0,00 & 0,00 \\
\hline 2 & $\begin{array}{ll}\text { Капітальний ремонт водопровідної } \\
\text { мережі по вул. Калініна у м. } \\
\text { Олександрія } \\
\text { області }\end{array}$ & 421,25 & 351,04 & 0,00 & 0,00 \\
\hline 3 & $\begin{array}{l}\text { Реконструкція насосної станції III } \\
\text { підйому по вул. Паркова, } 2 \text { в м. } \\
\text { Світловодськ }\end{array}$ & 932,02 & 776,68 & 29,28 & 24,40 \\
\hline 4 & Реконструкція ВОС в смт. Смоліне & 600,00 & 500,00 & 216,05 & 180,04 \\
\hline 5 & $\begin{array}{l}\text { Модернізація існуючих } \\
\text { обліку }\end{array}$ & 17,86 & 14,88 & 19,50 & 16,25 \\
\hline 6 & $\begin{array}{l}\text { Оснащення будинкових } \\
\text { обліку в м. Олександрія }\end{array}$ & 347,75 & 289,79 & 255,83 & 213,19 \\
\hline 7 & $\begin{array}{l}\text { Оснащення будинкових } \\
\text { обліку в м. Світловодськ }\end{array}$ & 455,02 & 379,18 & 84,79 & 70,66 \\
\hline 8 & $\begin{array}{l}\text { Оснащення будинкових } \\
\text { обліку в м. Кропивів }\end{array}$ & 1442,54 & 1202,12 & 658,83 & 549,02 \\
\hline 9 & $\begin{array}{lr}\text { Автоматизація } & \text { системи } \\
\text { водопостачання } & \text { шляхом } \\
\text { встановлення датчиків тиску та } \\
\text { рівнемірів в м. Світловодськ, } \\
\begin{array}{l}\text { Олександрія, } \\
\text { Кропивницький }\end{array} \\
\text { Знам’янка, }\end{array}$ & 120,00 & 100,00 & 136,75 & 113,96 \\
\hline 10 & $\begin{array}{l}\text { Модернізація системи видалення } \\
\text { повітря } 3 \text { водопровідних мереж } \\
\text { ОКВП «Дніпро-Кіровоград» }\end{array}$ & 124,74 & 103,95 & 0,00 & 0,00 \\
\hline 11 & 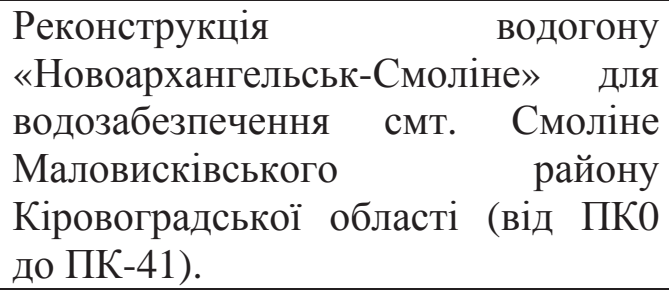 & 90,20 & 75,17 & 0,00 & 0,00 \\
\hline
\end{tabular}


Продовження таблиці 1

\begin{tabular}{|c|c|c|c|c|c|}
\hline 12 & 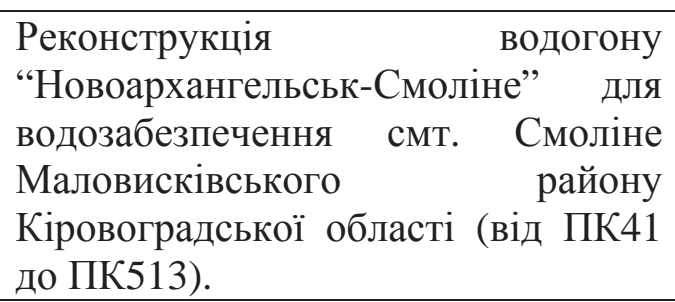 & 2976,79 & 2480,66 & 0,00 & 0,00 \\
\hline Разом & & 7871,22 & 6559,35 & 1401,03 & 1167,52 \\
\hline \multicolumn{6}{|c|}{ Водовідведення } \\
\hline 1 & $\begin{array}{l}\text { Реконструкція } \quad \text { каналізаційних } \\
\text { очисних споруд м. Знам’янка, вул. } \\
\text { Будьонного, } 207\end{array}$ & 1059,22 & 882,68 & 0,00 & 0,00 \\
\hline 2 & $\begin{array}{lr}\text { Реконструкція } & \text { каналізаційних } \\
\text { очисних споруд } \\
\text { Кіровоградської } \\
\text { Коригування }\end{array}$ & 1288,12 & 1073,43 & 0,00 & 0,00 \\
\hline 3 & $\begin{array}{l}\text { Реконструкція } \quad \text { каналізаційних } \\
\text { очисних споруд } 3 \text { новим } \\
\text { будівництвом цеху механічного } \\
\text { зневоднення осаду стічних вод по } \\
\text { вул. Байкальська, } 107 \text { в м. } \\
\text { Кропивницький Кіровоградської } \\
\text { області }\end{array}$ & 1136,59 & 947,16 & 0,00 & 0,00 \\
\hline 4 & $\begin{array}{l}\text { Встановлення технологічних вузлів } \\
\text { обліку } 3 \text { передачею даних стічних } \\
\text { вод в м. Смоліно КНС №3 }\end{array}$ & 136,75 & 113,96 & 0,00 & 0,00 \\
\hline Разом & & 3620,68 & 3017,23 & 0,00 & 0,00 \\
\hline Всього & & 11491,90 & 9576,58 & 1401,03 & 1167,52 \\
\hline
\end{tabular}

Джерело: [3].

Проте, всі перелічені заходи, лише частково вирішують проблему покращення якості роботи системи водопостачання та водовідведення ОКВП «Дніпро-Кіровоград», оскільки власних коштів для модернізації всієї водопровідно-каналізаційної системи у підприємства не вистачає.

Для покращення i розвитку сектору водопостачання та водовідведення i поводження 3 твердими побутовими відходами у м. Кіровограді обласне комунальне виробниче підприємство «Дніпро - Кіровоград» розпочало співпрацю з Світовим банком в рамках «Другого проекту розвитку міської інфраструктури».

В листопаді 2014 року було підписано Договори субкредитування між Міністерством фінансів України, Міністерством регіонального розвитку, будівництва та житлово-комунального господарства України, Кіровоградською обласною радою, Національною комісією, що здійснює державне регулювання у сферах енергетики та комунальних послуг та обласним комунальним виробничим підприємством «ДніпроКіровоград» «Про використання Позики, що надається Україні Міжнародним банком реконструкції та розвитку (Угода про позику «Другий проект розвитку міської інфраструктури»)» та «Про використання Позики, що надається Україні Міжнародним банком реконструкції та розвитку (діючим в якості виконавця від імені Фонду чистих технологій) (Угода про позику «Другий проект розвитку міської інфраструктури») $[6 ; 14]$. 
Сума позики складає 44,3 млн. доларів США. Отриманий кредит є надзвичайно важливим для підприємства, до того ж, термін його повернення складає 20 років, а відсотки за кредитом - 1,5\% річних.

За рахунок позики ОКВП «Дніпро-Кіровоград» планує забезпечити населення Кіровоградської області питною водою нормативної якості, підвищити ефективність та надійність функціонування ВКГ, здійснити роботи з ремонту та реконструкції об'єктів ВКГ, зменшити виробничі витрати підприємства із надання послуг централізованого водопостачання та водовідведення, встановити економічно обгрунтовані тарифи на послуги, передбачені ліцензійною діяльністю.

Підприємство наполегливо працює у напрямку освоєння міжнародних інвестицій Світового банку. У 2018 р. розроблено Інвестиційну програму обласного комунального виробничого підприємства «Дніпро - Кіровоград» на 2018 - 2020 роки (зміни за результатами коригування заходів на 2019 рік). В ній розкрито заходи інвестиційної програми підприємства, виконання яких передбачено проектом «Розвиток міської інфраструктури - 2»; розраховано витрати з повернення тіла кредиту та відсотків за користування кредитними коштами Міжнародного банку реконструкції та розвитку і Фонду чистих технологій (дол. США); Річний інвестиційний план підприємства на 2019 рік та Фінансовий план використання коштів інвестиційної програми і її врахування у структурі тарифів на 2017 - 2020 роки [4].

Підприємство планує якнайшвидше реалізувати Інвестиційну програму, з метою прискорення економічного розвитку підприємства, сприяння швидкому формуванню грошових потоків у вигляді прибутку та амортизаційних відрахувань, скорочення термінів використання кредитних ресурсів.

Фінансове забезпечення Інвестиційної програми на 2017-2020 рр. становить 722 млн. 754 тис. грн., в тому числі в 2019 році 578 млн. 464 тис. грн. без ПДВ, з них 519 млн. 776 тис. грн. без ПДВ за рахунок позики Світового банку в рамках «Другого проекту розвитку міської інфраструктури», 17 млн. 57 тис. грн. без ПДВ (з них 12 млн. 68 тис. грн. на послуги водопостачання та 4 млн. 989 тис. грн. на послуги водовідведення) за рахунок амортизаційних відрахувань, 41 млн. 631 тис. грн. - за рахунок виробничих інвестицій з прибутку [4].

Виконання інвестиційної програми забезпечить:

- зниження витрат матеріальних і енергетичних ресурсів у процесі водопідготовки, транспортування питної води, водовідведення та очистки стоків, що дозволить в подальшому зменшити економічне навантаження на тариф за послуги централізованого водопостачання і водовідведення;

- впровадження на підприємстві сучасних технологій;

- стабілізацію роботи;

- удосконалення обліку питної води та стічних вод;

- поліпшення якості надання послуг 3 питного водопостачання та водовідведення.

ОКВП «Дніпро-Кіровоград» в рамках співпраці з Світовим банком у форматі «Другого проекту розвитку міської інфраструктури» розробило заходи, що плануються до виконання (табл. 2). 
Таблиця 2 - Заходи ОКВП «Дніпро - Кіровоград» в рамках проекту Світового банку «Другого проекту розвитку міської інфраструктури»

\begin{tabular}{|c|c|c|c|}
\hline $\begin{array}{l}\text { № } \\
\text { 3/ח }\end{array}$ & Опис завдання & $\begin{array}{c}\text { Обгрунтування необхідності } \\
\text { інвестицій }\end{array}$ & $\begin{array}{l}\text { Технічні та економічні } \\
\text { вигоди, що очікуються }\end{array}$ \\
\hline 1 & 2 & 3 & 4 \\
\hline 1 & $\begin{array}{l}\text { Передконтрактні } \\
\text { послуги та } \\
\text { технічний нагляд }\end{array}$ & \begin{tabular}{lcr}
\multicolumn{3}{l}{ Включають в себе: допомогу та } \\
консультації & клієнту під час \\
торгів, оцінки заявок та надання \\
технічної допомоги; здійснення \\
технічного & нагляду & за \\
будівництвом & 3 & метою \\
забезпечення & своєчасного та \\
задовільного & завершення & робіт \\
згідно 3 & договорами & між \\
клієнтом і підрядником.
\end{tabular} & \\
\hline 2. & $\begin{array}{lr}\text { Реконструкція } \\
\text { Дніпровської } \\
\text { водоочисної } \\
\text { станції } \\
\text { «Дніпро } \\
\text { Кіровоград» }\end{array}$ & 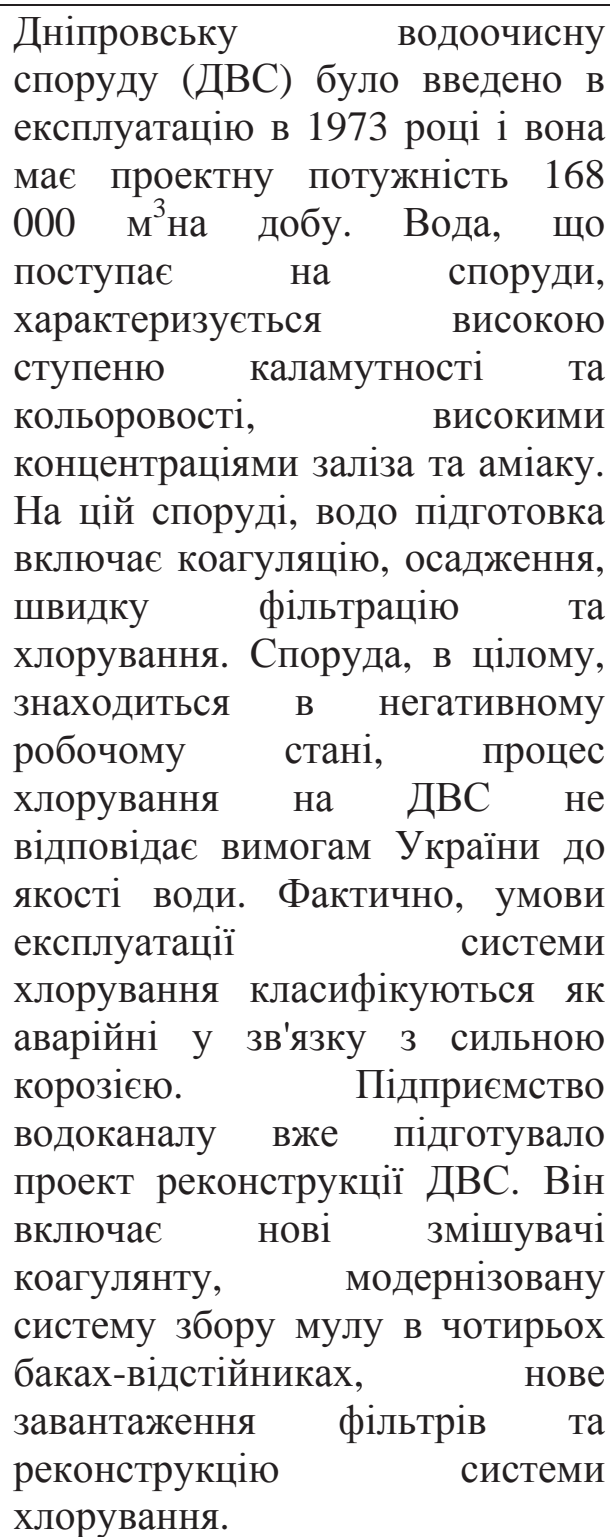 & $\begin{array}{l}\text { ДВС є головною } \\
\text { водоочисною спорудою в } \\
\text { системі водопостачання } \\
\text { м. Кропивницький. } \\
\text { Якщо робота цієї } \\
\text { споруди припиниться, } \\
\text { більша частина } \\
\text { населення м. } \\
\text { Кропивницький } \\
\text { залишиться без послуг } \\
\text { водопостачання. } \\
\text { Запропонований захід } \\
\text { забезпечить } \\
\text { інфраструктуру, що } \\
\text { необхідна для } \\
\text { покращення якості } \\
\text { питної води відповідно } \\
\text { до українських } \\
\text { стандартів. } \\
\text { Запропонована дія } \\
\text { призведе до } \\
\text { підвищення ефективності } \\
\text { очищення води і } \\
\text { скорочення витрат, } \\
\text { пов’язаних з } \\
\text { використанням хімічних } \\
\text { реагентів. }\end{array}$ \\
\hline
\end{tabular}


Продовження таблиці 2

\begin{tabular}{|c|c|c|c|}
\hline 3 & $\begin{array}{l}\text { Реконструкція } \\
\text { міських мереж } \\
\text { м.Кропивницький } \\
\text { та ділянок } \\
\text { водогону «Дніпро } \\
\text { - Кіровоград» }\end{array}$ & $\begin{array}{l}\text { Мережа } \\
\text { складається з } 216 \text { км водогону } \\
\text { «Дніпро-Кіровоград» та } 811,1 \text { км } \\
\text { трубопроводів } \\
\text { Кропивницький. Більше ніж } 75 \\
\% \text { трубопроводів має фізичний } \\
\text { знос більше } 74 \% \text {. }\end{array}$ & $\begin{array}{l}\text { Запропонована дія } \\
\text { включає заміну } \\
\text { найбільш зношеного } \\
\text { трубопроводу. Це } \\
\text { повинно привести до } \\
\text { зменшення втрат. } \\
\text { Зменшення втрат } \\
\text { принесе економічні } \\
\text { вигоди у вигляді більш } \\
\text { низьких витрат на } \\
\text { експлуатацію. }\end{array}$ \\
\hline 4 & $\begin{array}{l}\text { Переоснащення } \\
\text { лабораторій } \\
\text { водопостачання та } \\
\text { водовідведення }\end{array}$ & 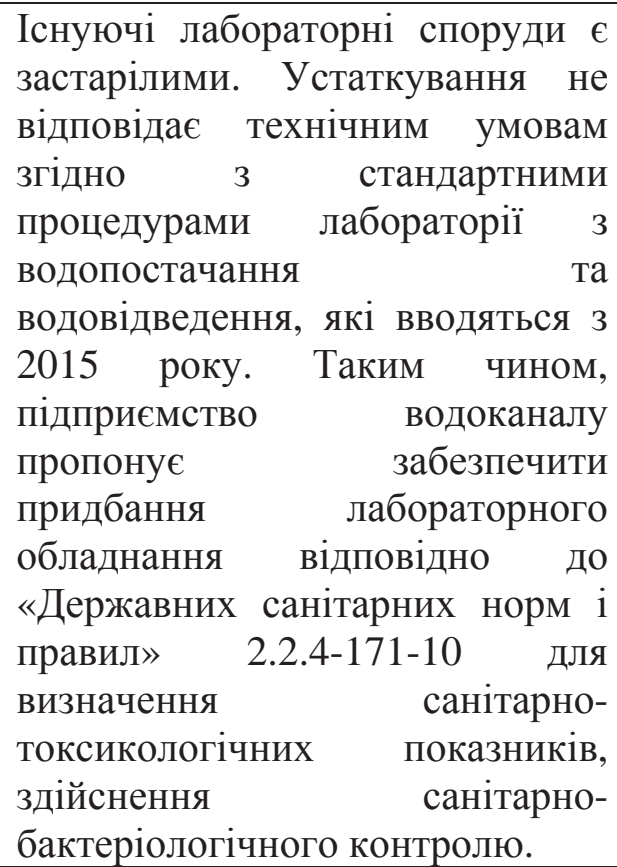 & $\begin{array}{l}\text { Tехнічні вдосконалення, } \\
\text { що передбачаються, } \\
\text { включають більш високу } \\
\text { надійність контролю } \\
\text { води і менший ризик } \\
\text { отримання помилкових } \\
\text { негативних } \\
\text { результатів. }\end{array}$ \\
\hline 5 & $\begin{array}{l}\text { Придбання } \\
\text { автотранспортної } \\
\text { техніки }\end{array}$ & 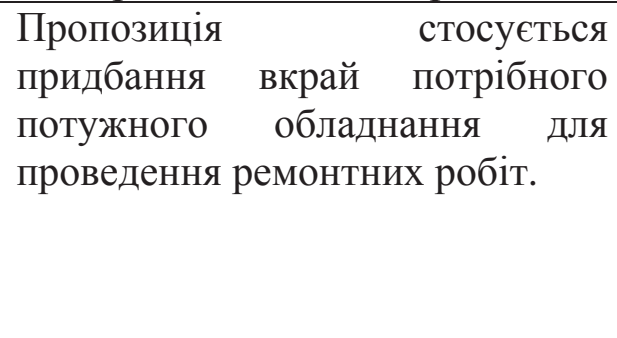 & $\begin{array}{l}\text { Придбання обладнання } \\
\text { що пропонується буде } \\
\text { корисним для } \\
\text { проведення термінового } \\
\text { ремонту на системах } \\
\text { водопостачання та } \\
\text { водовідведення. }\end{array}$ \\
\hline 6 & $\begin{array}{l}\text { Реконструкція } \\
\text { водопровідних } \\
\text { насосних станцій }\end{array}$ & 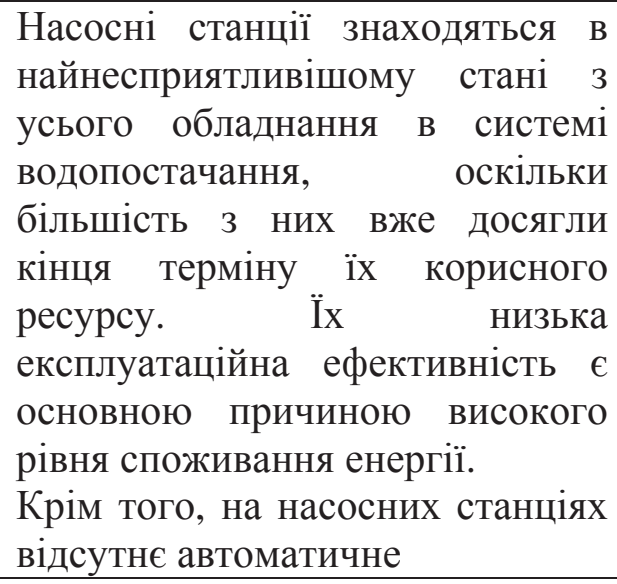 & 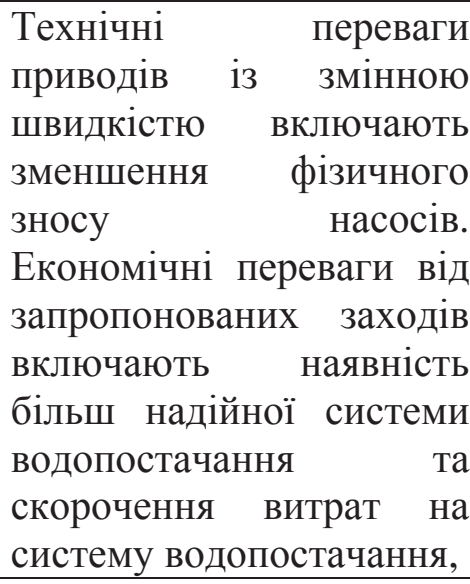 \\
\hline
\end{tabular}


Продовження таблиці 2

\begin{tabular}{|c|c|c|c|}
\hline & & $\begin{array}{lcr}\text { управління; } & \text { що також } \\
\text { негативний } & \text { вплив } \\
\text { ефективність } & \text { роботи насосних } \\
\text { станцій. } & & \end{array}$ & $\begin{array}{l}\text { тому що питома витрата } \\
\text { енергії } \quad \text { системою } \\
\text { водопостачання повинна } \\
\text { 3меншитися. }\end{array}$ \\
\hline 7 & $\begin{array}{l}\text { Реконструкція } \\
\text { каналізаційних } \\
\text { насосних станцій }\end{array}$ & 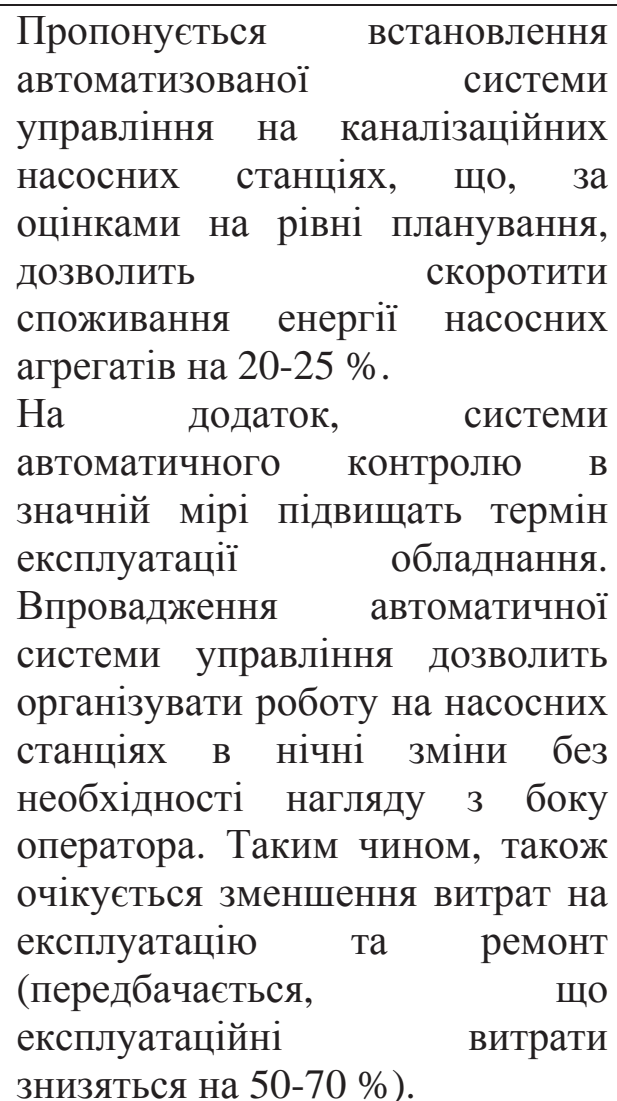 & \begin{tabular}{lr} 
Після & \multicolumn{2}{c}{ встановлення } \\
приводу із змінною \\
частотою, а також \\
відповідних систем \\
автоматизації, очікуване \\
зменшення \\
електричної \\
становитиме \\
$20 \%$.
\end{tabular} \\
\hline 8 & $\begin{array}{l}\text { Реконструкція } \\
\text { каналізаційних } \\
\text { очисних споруд } \\
\text { м. Кропивницький }\end{array}$ & 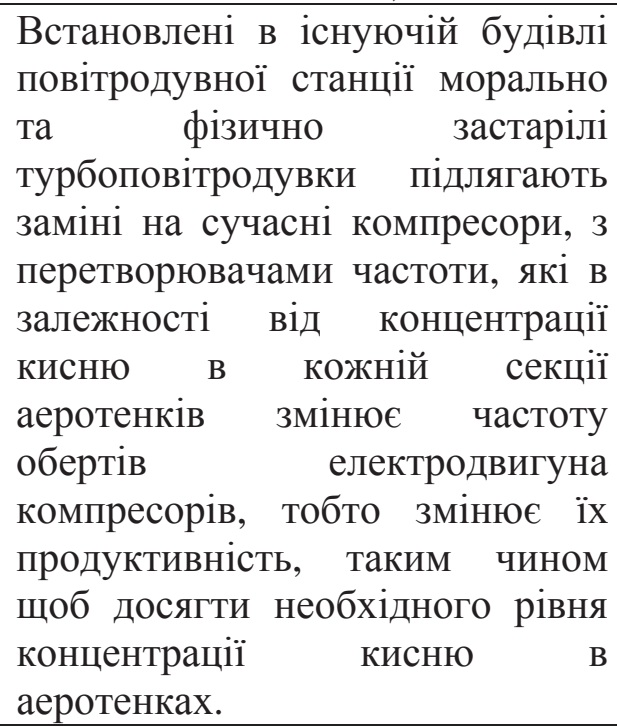 & $\begin{array}{l}\text { Суттєве скорочення } \\
\text { енергоспоживання на } \\
\text { каналізаційному } \\
\text { очисному комплексі } \\
\text { залежить від вибраної } \\
\text { технології очистки } \\
\text { та, необхідного для її } \\
\text { реалізації насосно - } \\
\text { повітродувного } \\
\text { обладнання. }\end{array}$ \\
\hline 9 & $\begin{array}{l}\text { Впровадження } \\
\text { системи } \\
\text { автоматизації та } \\
\text { диспетчеризації }\end{array}$ & $\begin{array}{l}\text { Впровадження єдиної системи } \\
\text { автоматизації і моніторингу } \\
\text { технологічних параметрів для } \\
\text { прийняття оперативних рішень } 3 \\
\text { ліквідації аварій та при збої в } \\
\text { роботі обладнання. }\end{array}$ & $\begin{array}{l}\text { Зменшення кількості } \\
\text { експлуатаційного } \\
\text { персоналу, зменшення } \\
\text { витрат електроенергії та } \\
\text { підвищення якості } \\
\text { надання послуг. }\end{array}$ \\
\hline
\end{tabular}

Джерело: [4]. 
Висновки та перспективи подальших досліджень. Дослідивши діяльність обласного комунального виробничого підприємства «Дніпро-Кіровоград» в напрямку залучення зарубіжних інвестицій, ми дійшли висновку, що реалізація підприємством проектів із зарубіжними інвестиціями Світового банку сприятиме нормалізації екологічної та соціальної обстановки в Кіровоградській області. Питна вода стане якіснішою; зменшаться втрати води, викидів парникових газів, забруднюючих речовин; покращиться якість стічних вод, що скидаються у водойми, підвищиться якість надання послуг з водопостачання та водовідведення тощо.

Друга фаза проекту «Розвиток міської інфраструктури» (ПРМІ-2) надасть обласному комунальному виробничому підприємству «Дніпро - Кіровоград» учаснику проекту, допомогу в підвищенні якості та надійності його послуг й ефективності використання енергії шляхом інвестування робіт з відновлення та заміни пошкоджених систем водопостачання, водовідведення та асоційованих з ними мереж та поліпшення екологічних та соціальних умов на території Кіровоградської області за рахунок вирішення проблеми очищення стоків.

Запорукою успішності цього проекту $\epsilon$ його соціальна i екологічна спрямованість, підтримка місцевої влади та досвід Світового банку щодо реалізації інвестиційних проектів в Україні.

Необхідність i важливість проблеми залучення іноземних інвестицій в комунальний сектор України, зумовлює складність їі розв'язання. Адже більшість питань, які при цьому потрібно вирішувати, є наскільки новими і незвичайними для українського суспільства, що в багатьох випадках підходи до їх розв’язання ще тільки окреслюються, тому питання співпраці вітчизняних підприємств із Світовим банком потребує подальших досліджень.

\section{Список літератури}

1. Гіроль М.М., Ковальський Д., Хомко В.Є., Гіроль А.М. Проблеми якості води в водопровідних мережах. Водопостачання та водовідведення. Виробничо-практичний журнал. 2008. Вип. 2. С. 121.

2. Гіроль М.М., Семчук Г.М. Ефективність систем водопостачання України як фактор національної безпеки держави. Надзвичайна ситуачія. Виробничо-практичний журнал. 2001. Вип. 5. С. 10-14.

3. Звіт про роботу ОКВП «Дніпро-Кіровоград» за I півріччя 2018 року. URL: https://dniprokirovograd.com.ua (дата звернення: 04.05.2019).

4. І Інвестиційна програма обласного комунального виробничого підприємства «Дніпро - Кіровоград» на 2018 - 2020 роки (зміни за результатами коригування заходів на 2019 рік). URL: https://dniprokirovograd.com.ua (дата звернення: 24.04.2019).

5. Інструкції з оцінки впливу на навколишнє середовище. Сфера застосування. Свропейська Комісія, Офіс офіційної публікації Європейських громад. Люксембург. 2001.

6. Національний звіт про якість питної води та умови постачання питної води в Україні. 2011. URL: http://wdk.dn.ua/sample-page (дата звернення: 24.04.2019).

7. Основні засади екологічної та соціальної оцінки для проектів водопостачання та водовідведення у містах: Харків, Кіровоград, Краматорськ, Тернопіль, Житомир, Київ, Коломия та Донецьк. Заходи забезпечення екокологічної та соціальної безпеки для підприємств - учасників другої фази проекту «Розвиток міської інфраструктури». URL: https://dnipro-kirovograd.com.ua (дата звернення: 04.05.2019).

8. Про житлово-комунальні послуги: Закон України в редакції від 07 черв. 2018 р.№ 2454-VIII. URL: https://zakon.rada.gov.ua/go/2454-19 (дата звернення: 02.05.2019).

9. Про Загальнодержавну цільову програму «Питна вода України» на 2011-2020 роки»: Закон України в редакції від 13 листоп. 2011 р. № 3933-VI. URL: https://zakon.rada.gov.ua/go/2455-15/ (дата звернення: 02.05.2019).

10. Про зовнішньоекономічну діяльність: Закон України в редакції від 07 лют. 2019 р. № 2473-VIII. URL: https://zakon. rada.gov.ua/go/959-12 (дата звернення: 04.05.2019).

11. Про інвестиційну діяльність: Закон Українив редакції від 08 черв. 2017p. № 2095-VIII. URL: https://zakon.rada.gov.ua/go/1981-19. (дата звернення: 03.05.2019). 
12. Проектна пропозиція для другої фази проекту «Розвиток міської інфраструктури», фінансованого Світовим Банком за рахунок коштів інвестиційної позики. Київ. 2013. 49 с.

13. Про режим іноземного інвестування: Закон України в редакції від 31 трав. 2016 р. № 1390. URL: https://zakon.rada.gov.ua/ laws/show/93/96-вр (дата звернення: 03.05.2019).

14. Проект розвитку міської інфраструктури - Підготовка комплексних техніко-економічних обгрунтувань та програм пріоритетних інвестицій у секторі водопостачання та водовідведення, які будуть фінансуватися міжнародними фінансовими організаціями в Україні: Харків, Кіровоград, Краматорськ, Тернопіль, Ужгород та Житомир. Звіт про поточний стан - Кіровоград. ТF №: TF091769. Проект №: Р095337. Кіровоград. 2014. 88 с.

15. Стан водопровідних мереж України та шляхи запобігання погіршенню якості питної води. Гіроль M.M., Гіроль А.М., Хомко В.С., Ковальський Д. URL:http://polypipe. info/news/238stanvodoprovidnuhmerezhukraini(дата звернення: 25.04.2019).

16. Технічне завдання. Підготовка документації щодо заходів забезпечення екологічного та соціального захисту для підприємств-учасників другої фази проекту «Розвиток міської інфраструктури» (ПРМІ-2). Світовий банк. 2013. 31 с.

\section{References}

1. Hirol, M.M., Kovalskyi, D., Khomko, V.Ie., \& Hirol, A.M. (2008). Problemy yakosti vody v vodoprovidnykh merezhakh [Problems of water quality in water supply networks]. Vodopostachannia ta vodovidvedennia. Vyrobnycho-praktychnyi zhurnal-Water supply and sewage system, Production and practical journal, 2, 1-21 [in Ukrainian].

2. Hirol, M.M., \& Semchuk, H.M. (2001). Efektyvnis tsystem vodopostachannia Ukrainy yak faktor natsionalnoi bezpeky derzhavy [Efficiency of water supply systems of Ukraine as a factor of national security of the state]. Nadzvychaina sytuatsiia. Vyrobnycho-praktychnyi zhurnal-Emergencysituation. Production and practical journal, 5, 10-14 [in Ukrainian].

3. Zvitprorobotu OKVP «Dnipro-Kirovohrad» za I pivrichchia 2018 roku [The OUPE Dnipro-Kirovohrad for the first half of 2018]. dnipro-kirovograd.com.ua. Retrieved from https://dnipro-kirovograd.com.ua [in Ukrainian].

4. Investytsiina prohrama oblasnoho komunalnoho vyrobnychoho pidpryiemstva «Dnipro - Kirovohrad» na 2018 - 2020 roky [Investment program of the regional municipal industrial enterprise "Dnipro Kirovograd" for 2018 - 2020]. Retrieved from https://dnipro-kirovograd.com.ua [in Ukrainian].

5. Environmental Impact Assessment Guidelines. Scope. European Commission, Office for Official Publications of the European Communities. (2001). Liuksemburh [in Ukrainian].

6. Natsionalnyi zvit pro yakist pytnoi vody ta umovy postachannia pytnoi vody v Ukraini [National Report on the Quality of Drinking Water and the Conditions for the Supply of Drinking Water in Ukraine]. 2011. wdk.dn.ua. Retrieved from http://wdk.dn.ua/sample-page [in Ukrainian].

7. Osnovni zasady ekolohichnoi ta sotsialnoi otsinky dlia proektiv vodopostachannia ta vodovidvedennia u mistakh: Kharkiv, Kirovohrad, Kramatorsk, Ternopil, Zhytomyr, Kyiv, Kolomyia ta Donetsk. Zakhody zabezpechennia ekokolohichnoi ta sotsialnoi bezpeky dlia pidpryiemstv - uchasnykiv druhoi fazy proektu «Rozvytok miskoi infrastruktury» [Basic principles of environmental and social assessment for water supply and sewerage projects in cities: Kharkiv, Kirovograd, Kramatorsk, Ternopil, Zhytomyr, Kyiv, Kolomyia and Donetsk. Environmental and social security measures for enterprises participating in the second phase of the Urban Infrastructure Development project]. dnipro-kirovograd.com.ua. Retrieved from https://dnipro-kirovograd.com.ua [in Ukrainian].

8. "Pro zhytlovo-komunalni posluhy”: Zakon Ukrainy v redaktsii vid 07 cherv. 2018 r. № 2454-VIII [“On Housing and Communal Services”: Law of Ukraine as of Jun 07, 2018 № 2454-VIII]. zakon.rada.gov.ua. Retrieved from https://zakon.rada.gov.ua/go/2454-19[in Ukrainian].

9. Pro Zahalnoderzhavnu tsilovu prohramu «Pytna voda Ukrainy» na 2011-2020 roky»: Zakon Ukrainy v redaktsii vid 13 lystop. 2011 r. № 3933-VI [On the National Target Program "Drinking Water of Ukraine" for 2011-2020 ": Law of Ukraine as of November 13, 2011 №. 3933-VI]. zakon.rada.gov.ua. Retrieved from https://zakon.rada.gov.ua/go/2455-15/ [in Ukrainian].

10. Pro zovnishnoekonomichnu diialnist: Zakon Ukrainy v redaktsii vid 07 liut. 2019 r. № 2473-VIII [On Foreign Economic Activity: Law of Ukraine as of February 07, 2019 No. 2473-VIII.]. zakon.rada.gov.ua. Retrieved from https://zakon.rada.gov.ua/go/959-12 [in Ukrainian].

11. Pro investytsiinu diialnist: Zakon Ukrainy v redaktsii vid 08 cherv. 2017r. № 2095-VIII [Investment activity: Law of Ukraine as of June 08, 2017 No. 2095-VIII.]. zakon.rada.gov.ua. Retrieved from https://zakon.rada.gov.ua/go/1981-19[in Ukrainian].

12. Project proposal for the second phase of the World Bank's Urban Infrastructure Development project funded by an investment loan. (2013). Kyiv [in Ukrainian]. 
13. Pro rezhym inozemnoho investuvannia: Zakon Ukrainy v redaktsii vid 31 trav. 2016 r. № 1390 [On the regime of foreign investment: Law of Ukraine as amended on May 31, 2016, No. 1390]. zakon.rada.gov.ua. Retrieved from https://zakon.rada.gov.ua/ laws/show/93/96-vr [in Ukrainian].

14. Proekt rozvytku miskoi infrastruktury - Pidhotovka kompleksnykh tekhniko-ekonomichnykh obgruntuvan ta prohram priorytetnykh investytsii u sektori vodopostachannia ta vodovidvedennia, yaki budut finansuvatysia mizhnarodnymy finansovymy orhanizatsiiamy $v$ Ukraini: Kharkiv, Kirovohrad, Kramatorsk, Ternopil, Uzhhorod ta Zhytomyr. Zvit pro potochnyi stan [Urban Infrastructure Development Project - Preparation of complex feasibility studies and priority investment programs in the water and wastewater sector to be funded by international financial institutions in Ukraine: Kharkiv, Kirovohrad, Kramatorsk, Ternopil, Uzhgorod and Zhytomyr. Current status report]. (2014). Kirovohrad. TF №: TF091769. Proekt №: P095337. Kirovohrad [in Ukrainian].

15. Hirol, M.M., Hirol, A.M., Khomko, V.Ie., \& Kovalskyi, D. (2013). Stan vodoprovidnykh merezh Ukrainy ta shliakhy zapobihannia pohirshenniu yakosti pytnoi vody [Status of water supply networks in Ukraine and ways to prevent deterioration of drinking water quality]. polypipe.info. Retrieved from http://polypipe.info/news/238-stanvodoprovidnuhmerezhukraini [in Ukrainian].

16. Specification. Preparation of documentation on measures for ensuring environmental and social protection for enterprises participating in the second phase of the Urban Infrastructure Development Project (PRMI-2). (2013). The World Bank [in Ukrainian].

Ivan Mytsenko, Professor, Doctor in Economics (Doctor of Economic Sciences)

Tetyana Reshytko, Associate Professor, PhD in Economics (Candidate of Economic Sciences)

Central Ukrainian National Technical University, Kropyvnytskyi, Ukraine

\section{Improvement of the Water Supply and Sewage System of the Public Regional Production Enterprise Dnipro-Kirovohrad with the Assistance of the World Bank's Investments}

The article deals with the legislative and regulatory framework of Ukraine in the sphere of water supply, sewage and foreign investment. It was investigated that the main activity of the enterprise is centralized water supply and sewage in Kirovohrad region. It was emphasized that public regional production enterprise DniproKirovohrad provides centralized water supply services in 16 communities of the region. It was found that due to insufficient financing of the enterprise, the infrastructure for drainage and wastewater treatment did not work properly or did not work at all, which caused permanent pollution of waterways.

The investment activity of the enterprise has been analyzed with the help of internal reserves. The nature of foreign investments within the framework of the project "Urban Infrastructure Development-2" and the directions of investment activity of the enterprise Dnipro-Kirovohrad in the framework of cooperation with the International Bank for Reconstruction and Development (World Bank) are explored. It is disclosed that the aim of the investment programme of the enterprise Dnipro-Kirovohrad is to improve the provision of the population of Kirovohrad region with drinking water of normative quality, to increase the efficiency and reliability of the operation of the water and sewage services, to carry out repairs and reconstruction works of the water and sewage facilities, to reduce the production costs of the enterprise for the provision of centralized water supply services and sewage, and to establish economically justified tariffs for services provided by licensing activities.

It has been proved that the implementation of the investment project will have a positive environmental and social impact, in particular, on improving the quality of drinking water; reduction of consumption and water losses, greenhouse gas emissions and pollutants emissions, energy consumption; improvement of the quality of waste water discharged into the reservoir; providing cities and villages with adequate access to water supply and sewage systems.

water supply and sewage systems, drinking water quality, foreign investments, World Bank investments 